\title{
HUBUNGAN PRODUKTIVITAS MAHASISWA DENGAN PANDEMI
}

STUDENT PRODUCTIVITY RELATIONSHIP WITH PANDEMI

\author{
Nor Khalisah \\ Program Studi Psikologi, Fakultas Kedokteran, Universitas Lambung Mangkurat, Jl. A. Yani \\ Km.36,00, Banjarbaru, 70714, Indonesia \\ Email : 2010914220031@mhs.ulm.ac.id
}

\begin{abstract}
ABSTRAK
Setiap mahasiswa tentunya harus memiliki kegiatan yang bersifat produktif, baik itu mahasiswa kedokteran maupun mahasiswa dari jurusan lain. Kegiatan produktif mahasiswa ini diharapkan mampu menumbuhkan dan memupuk kreativitas dalam setiap diri mahasiswa. Banyak mahasiswa di usia muda telah mampu bersaing dengan para senior-senior nya baik di dunia perindustrian maupun dunia pekerjaan lainnya. Namun dibalik itu semua tentunya masih banyak kita jumpai mahasiswa Indonesia yang tidak mampu bersaing bahkan ketika telah lulus sendiri mereka tetap tidak mampu bersaing dengan kehidupan yang sesungguhnya. Tujuan penelitian ini adalah mengetahui sejauh mana hubungan keterkaitan antara tingkat produktivitas Mahasiswa sebelum pandemi dan sesudah pandemi.
\end{abstract}

Kata Kunci : Hubungan, produktivitas, mahasiswa, pandemi.

\begin{abstract}
Every student must have productive activities, be it medical students or students from other majors. This student productive activity is expected to be able to heal and foster creativity in every student. Many students at a young age have been able to compete with their seniors in both the industrial world and other world of work. But behind all that, of course we still encounter many Indonesian students who are unable to compete even when they have graduated on their own they are still unable to compete with real life. The purpose of this study
\end{abstract}


was to determine the extent of the relationship between the level of student productivity before the pandemic and after the pandemic.

Keywords : Relationship, Productivity, Student, Pandemic

Mahasiswa adalah generasi penerus bangsa yang sedang menempuh pendidikan di perguruan tinggi, setelah menyelesaikan masa-masa sekolah tingkat menengah atas atau SMA. Produktif artinya seseorang mampu menghasilkan suatu karya yang memiliki manfaat bagi kehidupan, baik secara langsung maupun tidak langsung. Produktif bisa berupa barang, karya tulis, karya musik, karya seni kegiatan yang bermanfaat dan masih banyak lagi. Sedangkan pandemi sendiri adalah keadaan ketika suatu penyakit yang menyebar luas di seluruh dunia.

Mahasiswa sebagai salah satu kunci keberhasilan atau kesuksesan bangsa tentunya harus memiliki tingkat produktivitas yang tinggi, yang mampu memberikan efek kepada lingkungan sekitar maupun Indonesia sendiri.

Di saat pandemi seperti sekarang ini, banyak sekali orang-orang yang kehilangan produktivitasnya dikarenakan terlalu lama berdiam diri maupun kegiatan yang bias dilakukannya sangat dibatasi. Tentu hal ini akan mempengaruhi tingkat imajinasi yang dimiliki seseorang. Selain itu berada di dalam rumah dalam waktu yang panjang, melakukan kegiatan yang tidak bervariasi, tidak adanya interaksi social secara langsung dan adanya batasan dalam melakukan suatu kegiatan terbukti dapat meningkatkan resiko stress yang terjadi pada masyarakat. Selye (dalam Veitch \& Arkkelin, 1995) mendefinisikan stres sebagai tanggapan atau reaksi fisiologis dan psikologis seseorang terhadap stresor. Selye mengatakan bahwa stres adalah reaksi pertahanan secara umum yang dilakukan tubuh terhadap stresor (Putri, Anward\& Erlyani, 2017).

Stress yang dialami masyarakat ini terjadi lantaran adanya perubahan gaya hidup yang signifikan membuat sebagian masyarakat termasuk mahasiswa kesulitan bahkan tidak mampu beradaptasi dengan keadaan yang sekarang ini. Perubahan yang ada pada masa ini individu banyak mengalami perubahan-perubahan baik perubahan secara fisik, kognitif, maupun secara psikososioemiosional, untuk menuju kepribadian yang semakin matang dan bijaksana (Afnan, Fauzia, \& Tanau, 2020). Jika terus dibiarkan berlanjut stress ini bias saja akan menyebabkan depresi. 
Hal-hal seperti ini kemungkinan besar bisa dicegah dengan meningkatkan intensitas kegiatan produktif dalam diri seseorang agar tidak terjadi kebosanan dalam dirinya. Selain itu dengan menjadi produktif, seseorang juga dapat merasakan hasil positif dari kegiatannya tersebut baik bagi dirinya sendiri maupun bagi orang banyak.

Kondisi pandemi seperti sekarang ini sebenarnya juga telah membuat berbagai perusahaan untuk melakukan inovasi baru agar bisa menyesuaikan dengan keadaan. Seperti misalnya kita yang tadinya belajar secara tatap muka sekarang terpaksa harus belajar melalui virtual class online. Maka tentu saja ada peran dari berbagai perusahaan startup untuk dapat mendukung kegiatan belajar online. Di samping itu kita semua mau tidak mau harus bisa menggunakan teknologi untuk kepentingan belajar. Kita yang tadinya merasa tidak perlu dan tidak mau belajar teknologi dengan adanya pandemi ini terpaksa harus bias menggunakan berbagai teknologi baru dalam dunia pendidikan.

Sebenarnya dalam setiap situasi pasti memiliki sisi positif dan sisi negatif. Seperti kondisi sekarang ini sisi positifnya ialah hampir semua orang sekarang bisa menggunakan teknologi online dan saat ini kita memiliki lebih banyak waktu yang dapat dihabiskan bersama keluarga. Sedangkan sisi negatifnya adalah banyak orang yang kehilangan lapangan pekerjaan selain itu banyak perusahaan yang harus tutup.

\section{KAJIAN LITERATUR}

Penelitian ini termasuk penelitian dengan jenis metode kajian literatur dengan mencari referensi yang berhubungan dengan "Hubungan Antara Produktivitas dan Pandemi" yang relevan.

\section{HASIL DAN PEMBAHASAN}

Kegiatan produktif yang dilakukan mahasiswa tentunya berasal dari kreativitas dan imajinasi yang kuat yang mampu diwujudkan dalam sebuah karya. Kreativitas dan imajinasi ini bisa didapatkan mahasiswa dari berbagai hal seperti pengalaman sosial, pengalam spiritual, yang terjadi pada dirinya. Hal ini bisa diperoleh dari lingkungan sekitar, lingkungan pertemanan, lingkungan pendidikan terutama dari dunia perkuliahan.

Selama masa perkuliahan seorang mahasiswa memiliki begitu banyak pengalaman baru yang bisa memperluas pengetahuan serta mendorong seorang mahasiswa untuk berpikir. Pikiran-pikiran dan pengetahuan baru inilah yang nantinya akan menumbuhkan produktivitas seorang mahasiswa. 
Di kala pandemi seperti sekarang ini, banyak hal yang terpaksa harus dilakukan secara virtual di dalam rumah. tentu hal ini membatasi pergerakan seseorang sehingga menurunkan kegiatan sosial yang dilakukannya. Hal-hal yang tadinya dilakukan bersama-sama dengan tujuan dapat saling berjumpa dan mengenal, sekarang justru tak bisa dilakukan.

Tampaknya diera pandemi ini banyak mahasiswa maupun orang awam yang kehilangan produktivitasnya lantaran kurangnya interaksi sosial secara langsung. Kurangnya interaksi sepertinya memberikan efek yang cukup besar bagi permasalahan produktivitas dikalangan masyarakat. Hal ini dikarenakan saat ini masyarakat menghabiskan kebanyakan waktunya untuk bersantai, malas-malasan dan melakukan kegiatan yang tidak membawa manfaat yang tidak menimbulkan kebahagiaan. Kebahagiaan itu sendiri dapat diartikan sebagai emosi positif yang terdiri masa depan, masa lalu dan masa sekarang (Seligman, 2005) dalam (Akbar, Erlyani, \& Zwagery, 2020).

Saat hal ini terjadi dalam jangka waktu yang panjang, tentu saja membuat seseorang kurang berpikir dan menyebabkan otak akan kesulitan dalam berpikir di kemudian hari ketika manusia sudah kembali menjalankan kehidupan seperti di saat sebelum pandemi. Mahasiswa sendiri misalnya, setelah sekian lama bersantai dan melakukan kegiatan non-produktif mereka cenderung merasa lebih kesulitan dalam melakukan perkuliahan ketimbang mereka yang melakukan kegiatan-kegiatan yang produktif dan tetap belajar. Hal ini dikarenakan otak yang terlalu lama beristirahat sehingga menyebabkan memerlukan waktu yang cukup lama untuk kembali menghidupkan nya. sedangkan perkuliahan dengan sistem online seperti sekarang bukan suatu hal yang mudah. Selain akses yang terbatas dan cukup sulit kendala terhadap jaringan pun semakin memperparah keadaan. Bagi sebagian mahasiswa yang tidak begitu mengerti teknologi perkuliahan online hal ini tentu memberikan tekanan yang cukup besar. Di samping otak yang harus mulai kembali aktif berpikir, mahasiswa juga diharuskan mengerti tentang teknologi dan mengerti materi yang disampaikan oleh dosen secara virtual. Tentu bukan hanya mahasiswa yang terdampak pandemi ini, pelajar, guru, dosen, pengusaha, pebisnis dan masih bayak lagi orang yang kegiatannya sedikit terdampak pandemi.

Banyak mahasiswa yang tadinya aktif dalam berbagai organisasi dan melakukan kegiatan produktif terpaksa harus berada di rumah. Keadaan pandemi seperti sekarang ini tentu saja tidak dapat disalahkan sepenuhnya terkait penurunan produktivitas seseorang. Pengalaman spiritual juga dapat mempengaruhi tingkat produktivitas seseorang. Wahab dan Umiarso (2011) menyatakan orang yang cerdas secara spiritual mampu mempertahankan 
keharmonisan, keselarasan dalam kehidupannya sehari hari dan bersikap humanis terhadap sesama (Wahyuni, Mayangsari, \& Fauzia, 2017). Bagi mereka yang mau berpikir dan tetap kreatif tentu saja pandemi ini tidak akan terlalu mempengaruhi mereka. Mereka tetap mampu produktif walaupun kegiatan mereka sekarang ini dibatasi oleh berbagai hal. Banyak sekali hal-hal produktif yang bisa dilakukan dari rumah yang tentunya harus dimulai dengan motivasi yang kuat. Motivasi merupakan suatu kekuatan pendorong yang digunakan oleh seseorang dalam aktivitasnya. Motivasi terdiri dari dua hal yaitu motivasi instrinsik dan motivasi ekstrinsik. Motivasi instrinsik adalah motivasi yang berasal dari dorongan dalam diri individu, sedangkan motivasi ekstrinsik adalah motivasi yang dihasilkan dari salah satu baik positif atau negatif kemungkinan yang berasal dari luar diri individu (Chu dan Choi, 2005) dalam (Rachmah, Mayangsari, \& Akbar, 2015).

Pertama belajar memasak. Banyak sekali orang yang menjadi lebih suka memasak di kala pandemi seperti ini, selain karena mengisi waktu kosong memasak juga dilakukan untuk memenuhi kebutuhan. Dampak dari berdiam diri di rumah tanpa melalukan banyak hal menyebabkan rasa bosan. Orang-orang yang merasa bosan cenderung lebih sering mengonsumsi makanan. Bukan karena lapar namun dikarenakan dorongan dari rasa bosan sehingga ingin mengonsumsi sesuatu untuk mengisi waktu kosong dan mengusir rasa bosan.

Kedua menulis. Di masa pandemi seperti ini tentu saja kita memiliki lebih banyak waktu luang, keadaan ini tentu dapat kita manfaatkan untuk membuat suatu karya tulis. Karya tulis ini bisa berupa karya tulis ilmiah maupun karya tulis non ilmiah seperti misalnya menulis buku, jurnal, artikel, lirik lagu,naskah film maupun catatan harian. Ya, banyak hal dilakukan tanpa ditulis bukan saja tidak akan terdokumentasikan, tetapi akan hilang ditelan waktu. Aktivitas yang ditulis akan tersambung kepositifannya dari generasi ke generasi (Abbas, 2020). Menulis sendiri memiliki banyak manfaat, selain sebagai pengisi waktu luang menulis juga dapat menyalurkan bakat dan perasaan seseorang. Menulis juga mampu mendorong seseorang untuk berpikir dan fokus terhadap suatu permasalahan serta membantu seseorang untuk mengingat kembali pengetahuan yang mulai dilupakan. Selain itu menulis karya ilmiah akan membuat seseorang mampu merangkai kata-kata dan kalimat dengan baik sesuai dengan kaidah penulisan bahasa Indonesia. Menurut Abbas (2020) Yes. Mudah manakala mindset dibangun bahwa menulis itu mudah dan memudahkan (Abbas, \& Erlyani, 2020). 
Ketiga membaca dan belajar. Hawadi, (2002) mengemukakan dua faktor yang mempengaruhi komitmen terhadap tugas, yaitu faktor individual dan faktor situasional (Amini, Mayangsari, \& Zwagery, 2020) Tentu beberpa bulan yang lalu disaat awal-awal masa pandemi banyak orang yang memilih untuk mengistirahatkan tubuh dan pikirannya dari berbagai hal. Namun tentu saja hal ini tidak bisa dilakukan lagi, mengingat sudah cukup lama pandemi ini terjadi. Selain itu kita juga tidak tahu sampai kapan pandemi ini akan berlangsung. Jika masyarakat terus menghindari membaca dan belajar maka bukan tidak mungkin masyarakat kita akan mengalami kebodohan masal. Strategi pencapaian mutu pembelajaran sangat dipengaruhi oleh berbagai faktor yang kerap muncul saling berkaitan dan bersamaan dengan perubahan dinamisasi perkembangan masyarakat itu sendiri (Mutiani, 2015)

keempat bisnis online sekaligus melakukan hobi. Bisa dikatakan saat ini pebisnis dan pengusahalah yang paling terdampak oleh pandemi ini. Banyak perusahaan dan bisnis yang mengalami penurunan omset, tentu saja hal ini menyebabkan pengusaha dan pebisnis harus banting stir dan berinovasi agar usaha dan bisnis nya tidak sampai ditutup. Sebagai mahasiswa seharusnya juga mampu melihat peluang dan memanfaatkan peluang-peluang bisnis tersebut seperti misalnya bisnis online. Sekarang ini telah banyak perusahaan yang membuka pasar online yang dapat di akses oleh siapa saja termasuk mahasiswa. Jika merasa kurang cocok dengan pasar online mahasiswa bisa saja memulai usahanya sendiri seperti menjual produknya secara online di dareah sekitar nya. Namun tetu saja target konsumennya tidak akan seluas pasar online. Selain itu Ada banyak definisi perilaku konsumen, satu diantaranya sebagaimana definisi dari Engel \& Miniard (1994) bahwa perilaku konsumen (customer behavior) adalah tindakan-tindakan individu yang secara langsung terlibat dalam mendapatkan dan mempergunakan barang-barang dan jasa termasuk di dalamnya proses pengambilan keputusan dalam persiapan dan penentuan pada kegiatan-kegiatan tersebut (Nasruddin, Syahruddin, Mattiro, \& Riadi, 2020). Mahasiswa dan orang awam bisa mulai bisnis online seperti menjual barang kebutuhan primer, sekunder dan tersier. Apalagi saat ini masyrakat mulai menyukai membeli barang bekas. Tentu ini menambah peluang untuk memulai bisnis dengan modal kecil namun untung yang lumayan besar.

\section{KESIMPULAN DAN SARAN}

Hasil dari penelitian menunjukkan bahwa ada berbagai kegiatan produktif yang bisa dilakukan oleh seorang mahasiswa. Selain itu tingkat stress mahasiswa juga merupakan hal 
yang dapat mempengaruhi produktivitas seseorang. Oleh karena itu dapat di simpukan bahwa hubungan produktivitas mahasiswa dengan pandemi sangat besar, karena banyak orang yang kehilangan produktivitasnya selama masa pandemi.

Dengan mengetahui berbagai kegiatan produktif dan kaitan antara produktivitas dengan pandemi seharusnya bias membuat mahasiswa menjadi lebih produktif lagi dan mulai memikirkan inovasi baru apa yang bias mereka buat agar dapat dimanfaatkan oleh diri sendiri dan oleh banyak orang.

\section{DAFTAR PUSTAKA}

Putri, D. U. M., Anward, H. H., \& Erlyani, N. (2017). Peranan Penyesuaian Diri terhadap Stres Akibat Kemacetan pada Mahasiswa Fakultas Kedokteran Universitas Lambung Mangkurat Banjarmasin. Jurnal Ecopsy, 3(2).

Afnan, A., Fauzia, R., \& Tanau, M. U. (2020). HUBUNGAN EFIKASI DIRI DENGAN STRESS PADA MAHASISWA YANG BERADA DALAM FASE QUARTER LIFE CRISIS. Jurnal Kognisia: Jurnal Mahasiswa Psikologi Online, 3(1), 23-29.

Akbar, G. H., Erlyani, N., \& Zwagery, R. V. (2020). HUBUNGAN KEBAHAGIAAN DENGAN PERILAKU ALTRUISME PADA MASYARAKAT SEKITAR TAMBANG ASAM-ASAM. Kognisia prodi Psikologi FK ULM, 1(2), 95-101.

Wahyuni, R., Mayangsari, M. D., \& Fauzia, R. (2017). Hubungan kecerdasan spiritual dengan perilaku prososial pada perawat di rumah sakit islam banjarmasin. Jurnal Ecopsy, 3(3).

Rachmah, D. N., Mayangsari, M. D., \& Akbar, S. N. (2015). Motivasi belajar sebagai mediator hubungan kecerdasan adversitas dan prokrastinasi akademik pada mahasiswa yang aktif berorganisasi. Jurnal Cakrawala Pendidikan, 34(2).

Abbas, E. W. (2020). Menulis Artikel Jurnal Internasional.

Abbas, E. W., \& Erlyani, N. (2020). Menulis di Kala Badai Covid-19.

Amini, M., Mayangsari, M. D., \& Zwagery, R. V. (2020). Hubungan antara Kemandirian Belajar dengan Komitmen Tugas pada Mahasiswa Program Studi Psikologi. Jurnal Kognisia: Jurnal Mahasiswa Psikologi Online, 2(2), 149-152. 
Mutiani, M. (2015). Pemanfaatan Puisi Sebagai Sumber Belajar Ips Untuk Menumbuhkan Kesadaran Lingkungan Peserta Didik Di SMP Negeri 6 Banjarmasin. Jurnal Pendidikan Ilmu Sosial, 24(2), 199-208.

Nasruddin, N., Syahruddin, S., Mattiro, S., \& Riadi, S. (2020). PEMETAAN POTENSI KREDIT PEDAGANG KALIMANTAN SELATAN. 